\title{
A STUDY OF THE PROFESSIONAL IMAGE OF THE DEPARTMENT OF PHYSIOTHERAPY AT THE TYGERBERG HOSPITAL COMPLEX
}

\author{
E. MOUTON. B. Verpl., B.A. (Hons. Sielk.) (Stellenbosch)*
}

\begin{abstract}
SUMMARY
In this study the professional image of the Deparment of Physiotherapy as observed by physicians, physiolherapists, paramedical staff and laymen (patients) was looked at. The Nominal Group Technique (N.G.T.) was used to develop the Semantic Differential (S.D.) which was used as the criterion of measurement. In the results, the afore-mentioned groups indicated a positive image of the Department of Phy siotherapy and there seems to be a minimal difference in inage observation amongst the different groups.
\end{abstract}

Image rescarch has been used in the past for different projects. particularly in the field of marketing research in order to stimulate two-way communication between consumer and producer (Anastasi, 1964). "Image" is a concept which refers to the conceptualized notion of what we know. An image is therefore the connotation of what we believe to be the truth (Spoelstra, 1976). In the literature on the subject different approaches to the concept image are found. These vary from a personality speculation of the concept on the one hand, to a trend to define "image" as an attitude, on the other. By using the term professional image, the emphasis moves towards the profession and its attendant behaviour.

In this study the professional image as a reflection of the attitudes of individuals towards the Department of Physiotherapy was looked at. Attitudes arc often defined as tendencies to react favourably or unfavourably to specific

\footnotetext{
*Department of Personnel Development, Tygerberg Hospital.

Received 11 October I982.
}

\section{OPSOMMING}

In hierdie studie word die professionele beeld van die Deparlement Fisiolerapie soos wargeneem deat dokters, fisiolerapeule, paranediese personeel an leke (pasiënle). beskou. Die Nominale Groepregniek (N.G.T.) is gebruik om die Semantiese Differensiaal (S.D.) wat gebruik is as die meringskriterion, te onlwikkel. In die resullate het bogenoemde groepe "n posiliewe beeld van die Deparlement Fisioterapie anngedui en daar blyk 'n minimale verskil in beeldwaaneming assen die verskillende groepe te wees.

stimuli (Anastasi, 1968). It was possible to use one of severaff available attitude measurement techniques for this study by viewing "image" as a function of attitudes.

The Semantic Differential developed by Osgood (1952) as a criterion for the psychological meaning of concepts, has been used in the past for similar purposes. Images are the simplified impressions of people of an otherwise complex entity (Kottler. 1972). It was these "impressions" which were measured in this study.

The different professional groups used in this study were well known to the Department of Physiotherapy as can be seen from Table I.

It could therefore be cxpected that the selected groups would indicate certain attitudes, assumptions, actions and preferences in respect of the Department of Physiotherapy and would thus have a certain image of the profession. According to Spoelstra (1976) the information gained by image research can be used for several purposes:

- planning and promotion strategies

- evaluation of efficiency and internal re-organization and

- as a communication medium for better mutual understanding amongst concerned parties. 
Table 1. Degree of contact with the Department of Physiotherapy

$\begin{array}{lccc} & \text { Often } & \text { Seldom } & \text { Never } \\ \text { Physicians } & 57.9 \% & 41.5 \% & 1.3 \% \\ \text { Paramedical } & & & \\ \text { staff } & 66.4 \% & 33.7 \% & - \\ \text { Laymen } & 61.6 \% & 31.2 \% & 7.3 \%\end{array}$

The main benefit of this exercise was that it provided the opportunity to identify problem areas existing between physiotherapists and each of the selected groups. This could lead to mutual understanding and greater efficiency in the department concerned.

\section{METHOD}

The Scmantic Differential was selected as a criterion of measurement for two important reasons:

- It has been successfully applied in different contexts such as clinical diagnoses and therapy; consumer reactions to produets and trade names (Anastasi, 1968).

- It is not a specific test, but a very flexible approach to obtain scores, attitudes and other sentiments.

Research workers can therefore create a semantic differential by using Osgood's original scales or by using their own scales more suited to their own specific situation. The S.D. method consists basically of repeated ratings of one or other concept. In this case the concept "professional image" was rated against pairs of descriptive opposite adjectives on a 7 -point scale. On this scale 7 represented the positive pole and I the negative.

\section{THE QUESTIONNAIRE}

Originally 93 items were generated and selected by physiotherapists (clinical and teaching staff) by using the Nominal Group technique. The final list consisted of 25 itcms, and these were divided into 6 dimensions: effectiveness, dynamics, productivity, loyalty, scientific and professional aspects. The final questionnaire was presented in both official languages. with clear instructions, and additional information. such as occupation. English- or Afrikaans-speaking, as well as the degree of contact with physiotherapists, was also requested.

\section{TARGET GROUP}

The target group comprised persons in the Tygerberg Hospital Complex (physicians, paramedical staff, laymen (patients) and physiotherapists (teaching and clinical staff).

Number of questionnaires processed:

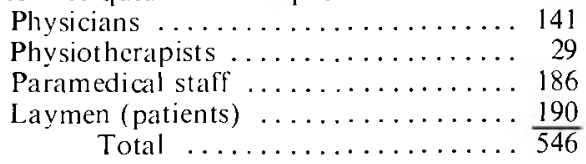

\section{RESULTS AND CONCLUSIONS}

The results were processed by a computer and are indicated throughout in terms of average. All 25 items were rated between 4,0 and 6,6 on the 7-point scale. It would therefore appear that physiotherapists maintain a positive image of their profession, and this attitude was confirmed by each of the selected groups.

A profile of each of the dimensions is illustrated in Fig. 1 and each dimension is illustrated separately in Figs. 2-6.

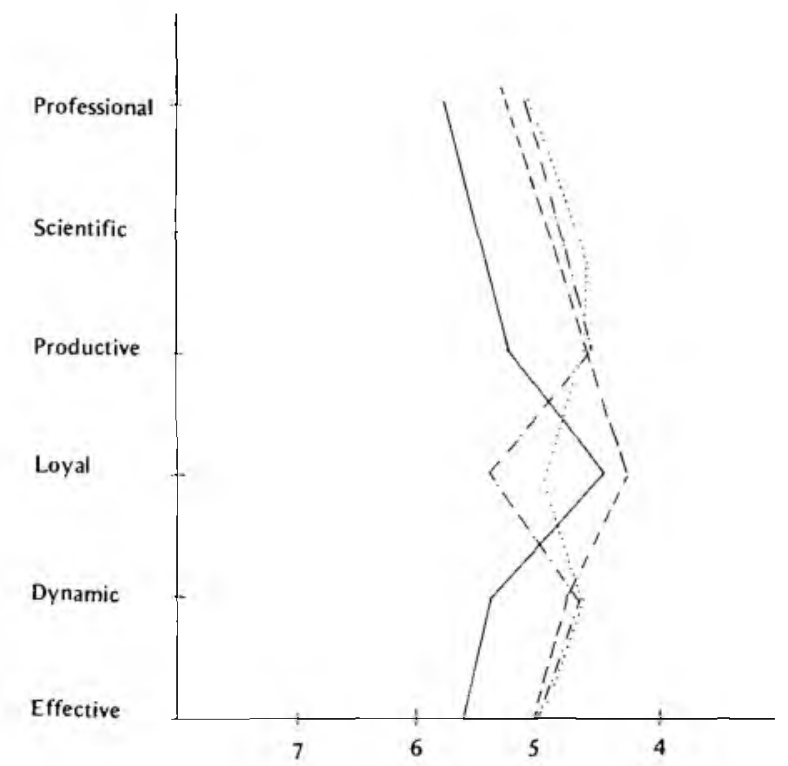

FIG. I. DIFFERENT DIMENSIONS

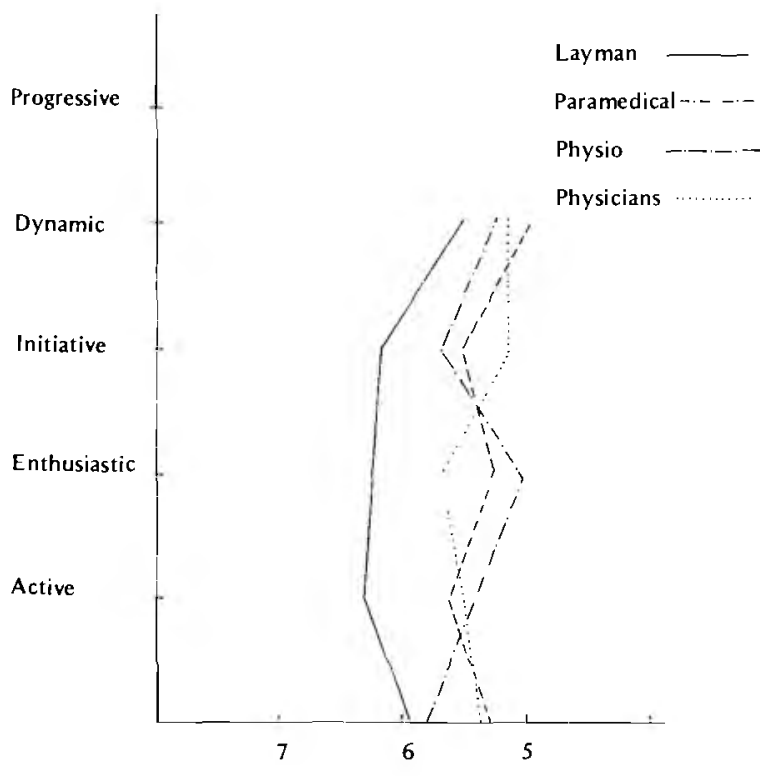

FIG. 2. DYNAMIC

It is fairly obvious that in the dynamic dimension the laymen (patients) tended to rate a more positive image in comparison with the other groups. The physiotherapists rated themselves less positively on the item enthusiastic.

In fig. 3 (productivity) there is a marked tendency by all the groups to award a low score to the item easily available. This item was rated lowest of all the other items: physiotherapists $(4,6)$; physicians $(4,3)$ : paramedical staff (4.0) and laymen (4.5).

The availability of physiotherapists seems to bc a problem-area. particularly as far as the paramedical staff are concerned, and may be attributed to several factors. It may be worthwhile to do an in-depth study on this issue. 


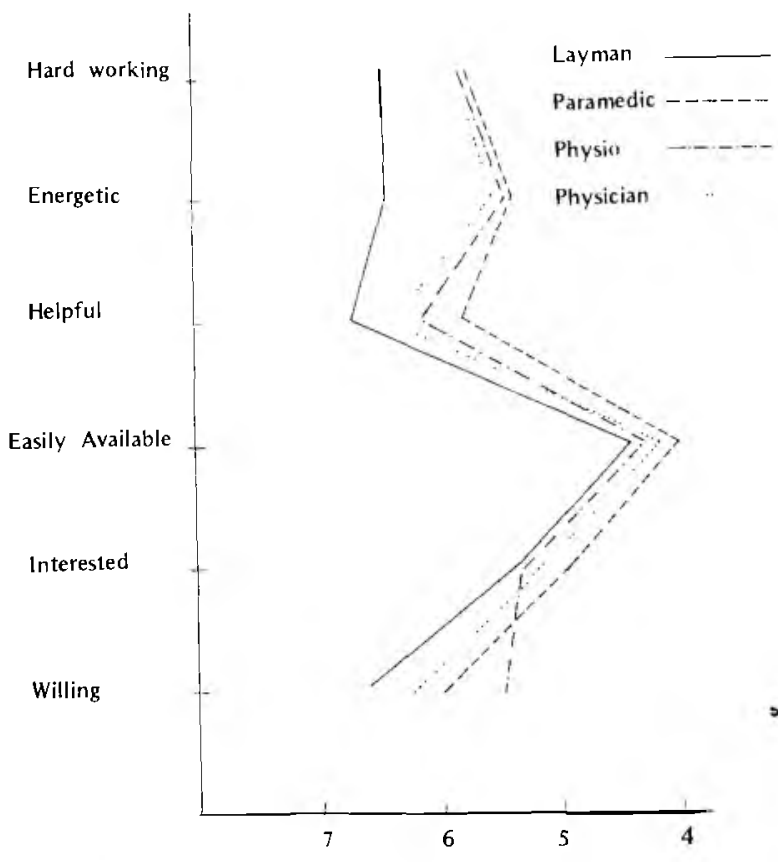

FIG. 3. PRODUCTIVITY

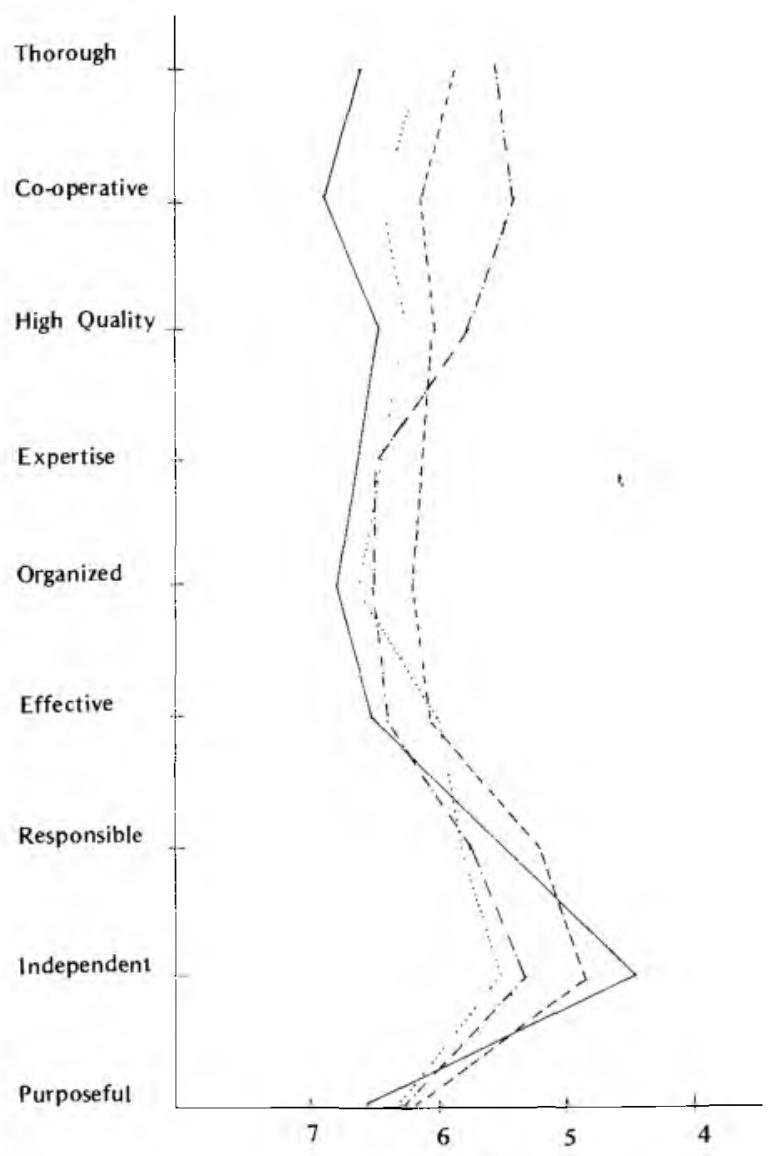

FIG. 4. EFFECTIVENESS
In comparison to the physiotherap ists $(5,5)$ the physicians $(4,6)$ rate the physiotherapy profession nore dependent (Fig. 5 effectiveness).

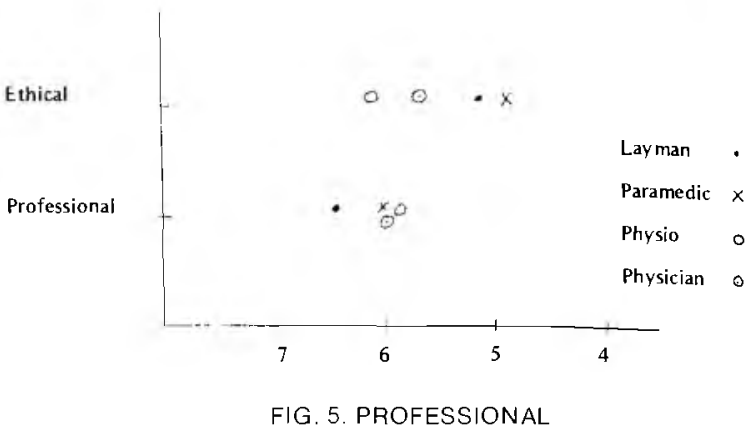

Although the physicians rated the items specialised and insight positively, they gave a lower rating than all the other selected groups (Fig. 6). The paramedical staff rated insight (5.5) lower than specialised (6.0).

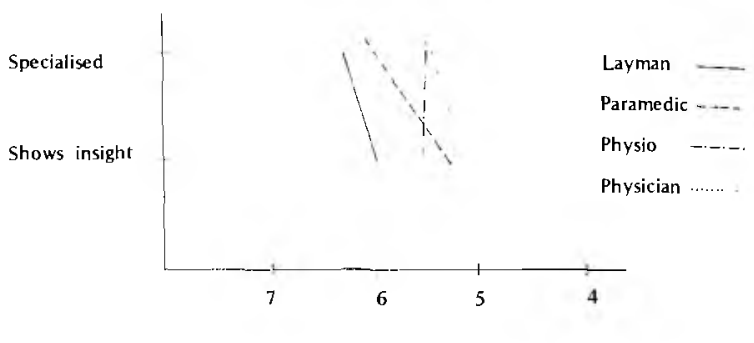

FIG. 6. SCIENTIFIC

In this item (Fig. 5) the physiotherapists regarded themselves less positively than the other groups. This information conlirimed the fact that it was because of the physiotherapists' underestimation of their own professional image that they requested this study.

There is another noticeable deviation in this dimension The laymen, who awarded all the other items the highesk rating, rated the ethical aspect $(5,3)$ lower than the physiotherapists $(6,1)$ and the physicians $(5,6)$. It may be a good idea to analyse this area to determine the immediate causc for this low rating.

\section{SUMMARY}

In this study the image observation of selected groups with regard to the profession of physiotherapy in the Tygerberg Hospital Conplex was looked at. The selected groups gave a very positive rating of the physiotherapy profession. This exercise was carried out at the request of the Department of Physiotherapy in order to evaluate their assumption that certain selected groups maintain a negative image of their professions. The opposite seems to be more acceptable. The value of this study lies in the results which indicate that the selected groups maintain a positive image of the professions of physiotherapy. The Physiotherapy Department. therefore. now has an indication of the attitude of the selccted groups towards their profession. 
Physiotherapy, June 1983, vol 39 , no 2

\section{References}

Anastasia, A. (1964). Field of Applied Psychology. McGraw-Hill. New York

Anastasia. A. (1968). Psychological Testing. The Macmillan Co. Canada.
Kotler, P. (1972). Marketing Management. Prentice-Hall. New Jersey.

Osgood, $\dot{C}$. E. (1952). The nature and measurement of meaning. Psychological Bullctin, 49, 197-237.

Spoelstra, H. I. J. (1976). 'n Bedryfsielkundige ondersoek na die verbruikersbeeld van handelsbanke in Suid-Afrika. Perspektiene in Bedryfsielkunde, 2, 1-23. 